 \\ Violence, Migration and the Making of the Refugee
}

\begin{abstract}
Sitting in his office, Khawaja Muhammad Zakariya thinks back to a tumultuous time decades ago when his country was violently split in two. His father hurried home one day, telling his young son they had to gather up their money and jewelry and leave their Muslim neighborhood immediately for an uncle's house across town. "The day we moved...that area was attacked, and many were killed and injured but we had left about two hours before," Zakariya said, recalling the violence-plagued months leading up to partition. The family later left Amritsar for good, taking only the valuables they could carry, joining other families on packed trains to Lahore. ${ }^{1}$
\end{abstract}

Many like Zakariya were forced to flee their homes, desperately clinging onto any valuables they could and escape towards an unknown future. There was chaos, a lack of control by the authorities, and general fear - a fear of an uncertain future, a fear that threatened the safety of their lives and their families and daughters. While the Boundary Commission had decided on the line that created India and Pakistan, the people on the ground were uncertain of the complete ramifications that the drawing of the line would have on their lives. The violence unleashed the mass forced migrations of millions, overnight turning them homeless and into state refugees. They had not chosen this path, the politicians had. Yet they were paying the price, with their lives shattered and livelihoods lost. The overriding narrative of partition is the accompanying violence; it is difficult to discuss this period without mentioning the senseless, and indeed, the intended violence that engulfed the region. It did not matter whether or not you were directly affected by the violence because most people will have experienced the repercussions of it, like Zakariya who fled before

1 'The retired professor of Urdu literature in his mid-70s spoke from his office at Punjab University in Lahore, just 50 kilometres (30 miles) from the Indian city of Amritsar. He was relaying his life history to a volunteer from The 1947 Partition Archive.' Anon., 'Murder, Rape and Shattered Families: 1947 Partition Archive Effort Underway,' accessed 8 May 2016, www.dawn.com/news/1169309. 
the violence claimed the lives of the people he grew up with. They witnessed the mass movement of people, which saw the demographic transformation of their neighbourhoods. They saw neighbours fleeing, either from the violence or from the ensuing violence that was spreading and engulfing everyone. It is difficult to fully understand how this region succumbed to the frenzy of violence in August 1947.

\section{Making Sense of the Violence}

There are a number of problems associated with the study of partition-related violence. These concern the extent to which it was spontaneous or planned, the degree to which any localised case studies can form part of a broader historical narrative and the extent to which partition violence differed from 'traditional' communal violence. ${ }^{2}$ These issues also raise the question of the extent to which the concepts of 'ethnic cleansing' and 'genocide' are useful in understanding the events in Punjab. These concepts are still relatively new in the study of partition but they are important in the wider historiographical context. In more recent research, writers such as Talbot, Anders B. Hansen and Paul Brass have attempted to bring the Punjab experience into the main literature on genocide, which has been largely dominated by the Holocaust perhaps because the contemporaneous events in Europe overshadowed those in Asia. ${ }^{3}$ More controversially, it could be argued that there is even a 'hierarchy of suffering' especially when we consider the vision of 'the emaciated women and men liberated from concentration camps'; ${ }^{4}$ anything else would become invisible in comparison with these shocking and disturbing images. The

2 Veena Das and Ashis Nandy, 'Violence, Victimhood and the Language of Silence,' in The Word and the World: Fantasy, Symbol and Record, ed. Veena Das (New Delhi: Oxford University Press, 1983).

3 Ian Talbot, ed., The Deadly Embrace: Religion, Violence and Politics in India and Pakistan 1947-2002 (Karachi: Oxford University Press, 2007); Anders B. Hansen, Partition and Genocide: Manifestation of Violence in Punjab 1937-1947 (New Delhi: India Research Press, 2002); Paul Brass, The Production of Hindu-Muslim Violence in Contemporary India (Seattle: University of Washington Press, 2003); and Ishtiaq Ahmed, The Punjab Bloodied, Partitioned and Cleansed (Karachi: Oxford University Press, 2012).

4 Vinay Lal, 'Partitioned Selves, Partitioned Pasts: A Commentary on Ashis Nandy's, “The Death of an Empire," accessed 17 July 2013, www.sscnet.ucla. edu/southasia/History/Independent/deathofempire.html. 
photographs used to depict partition by Margaret Bourke-White are equally disturbing: charred bodies and skeleton valleys, where vultures await to fill their bellies. ${ }^{5}$ These were the realities for millions of people.

At the most basic level, there is a dispute concerning the number of casualties arising from the partition-related violence; estimations vary considerably. It is in reality an impossible task to ascertain precise figures, and hence numbers have varied to suit political objectives. Indian nationalist writers have tended to lean towards the higher end of the spectrum and British writers have tilted towards the lower end, while in Pakistan the casualties represent the price of demanding a separate state from the domineering Hindu majority. This is hardly surprising as successive governments in both India and Pakistan have emphasised the problems the new states were able to surmount, while British governments have wished to preserve a legacy not marred by scenes of disorder. Veena Das also alludes to the fact that, in the process of naming the violence, the language falters due to the complexity of what is at stake. She argues, 'several kinds of social actors in any event of collective violence make it difficult to determine whether the event should be named as an instance of "sectarian," "communal," or "state-sponsored" violence. Is it described appropriately in the framework of "riots," "pogroms," "civil disturbances," "genocide," or a combination of these?'6 This vernacular does not even begin to understand the other complex layers present, where the victim and the perpetrator can be the same

The debate surrounding the number of casualties is long-standing. It was still a concern to Lord Mountbatten, even years after he relinquished the office of Viceroy of India. In a letter to Penderel Moon (a British civil servant), written 2 March 1962, he declared that he was 'keen that an authoritative record should be left for the historians long after I am dead...' though he was not particularly eager to defend himself at this stage, 'nor joining in the argument'. ${ }^{7}$ The inconsistency surrounding the casualties is obvious from the following extract in the letter by Mountbatten to Moon:

5 Khushwant Singh, Train to Pakistan (New Delhi: Lotus Collection, Roli Books, 2006), Photographs by Margaret Bourke-White, Time Life 1947.

6 Veena Das, Life and Words: Violence and the Descent into the Ordinary. (Berkeley, CA: University of California Press, 2006). E-book version.

7 Letters on Divide and Quit. Letter from Mountbatten of Burma, 2 March 1962. Mss Eur F230/34, India Office Records and Private Papers, British Library. 
My estimate has always been not more than 250,000 dead; and the fact that your [Moon] estimate is not more than 200,000 is the first realistic estimate I have seen. I have often wondered how the greatly inflated figures which one still hears were first arrived at, and I think that they were due largely to the wild guesses which were made in those emotional days after the transfer of power. That they still persist is very clear; for example, Mr Leonard Mosley's latest book gives, I understand, the figure of 600,000, and only the other day a backbench conservative MP told one of my staff that the figures were three million! ${ }^{8}$

In 1948, G. D. Khosla, who became Chief Justice of East Punjab High Court in 1959, led the Fact-Finding Commission by the Government of India to refute the Pakistani charge of genocide against Muslims emerging from United Nations debates over the Kashmir conflict. ${ }^{9}$ Although the reports were not made public, shortly after this, Khosla wrote Stern Reckoning. In this book he estimates the number of casualties to be around 200,000 to 250,000 non-Muslims and probably an equal number of Muslims, bringing the total to nearly 500,000. ${ }^{10}$ The historian Patrick French contends that deaths numbered closer to one million. ${ }^{11}$ In a recent interview, the Indo-Canadian writer Shauna Singh Baldwin suggested the figure of five million. ${ }^{12}$ Many of the police records were destroyed during the disturbances and due to the lawlessness of the state at the time; the records that do exist are unreliable in providing a comprehensive picture. Furthermore, it is difficult to calculate and differentiate between those that died directly due to the violence and those that died during the mass exodus through starvation, disease and other secondary factors. The truth in reality will never be known because it is an impossible task and, as Pandey suggests, casualty numbers are based on rumour and repetition, which continue to reverberate. ${ }^{13}$

8 Letters on Divide and Quit.

9 Tan Tai Yong and Gyanesh Kudaisya, The Aftermath of Partition in South Asia (London: Routledge, 2000), 253.

10 G. D. Khosla, Stern Reckoning: A Survey of Events Leading Up to and Following the Partition of India (New Delhi: Oxford University Press, 1949, reprint 1989), 299.

11 Patrick French, Liberty or Death: India's Journey to Independence and Division (London: Harper Collins, 1997).

12 Anjana Rajan, 'Memory's Harvest,' The Hindu, 14 May 2011.

13 Gyanendra Pandey, Remembering Partition: Violence, Nationalism and History in India (Cambridge: Cambridge University Press, 2001). 
Most understandings of communal violence in India have focused on postindependence Hindu-Muslim clashes. These are regarded as different from the partition violence, which arose in exceptional circumstances, sometimes seen as resulting from a temporary 'madness'. The 1947 partition riots are also often depicted as being different from 'traditional' communal clashes of the colonial era. Suranjan Das has produced the most comprehensive analysis of riots in colonial Bengal. He sees the 1941 Dacca Riots as marking a turning point in violence. ${ }^{14}$ Earlier riots were spontaneous and displayed a strong class orientation. The later violence was communally inspired and well organised. Das and Ashis Nandy see 'traditional' violence in terms of a feud in which communities continue to live together afterwards. ${ }^{15}$ Shail Mayaram terms this type of violence as 'consensual'. These were about 'renegotiating' local hierarchies of power, not about 'purifying' localities of a rival 'other'. Partition violence, however, was different in character; it was more intensive and moved beyond an exchange of violence in the public arenas to engulf the private arenas. An integral part of the violence was what might be termed 'power rape'. Such violence terminated community interaction. ${ }^{16}$

Studies that emphasise the 'spontaneous mob' features of the 1947 violence look back to writers such as Gustave Le Bon for inspiration. Collective crowd behaviour really emerges from the writings of Le Bon. In The Crowd: A Study of the Popular Mind, he suggests that all individual responses were lost in crowds. What emerged was a 'collective mind', which made people 'feel, think, and act in a manner quite different from that in which each individual of them would'. ${ }^{17}$ This would provide the anonymity needed to take away the personal responsibility of the participants. Emile Durkheim's ideas certainly resonant with Gustave Le Bon's, suggesting that crowd members are capable of conduct of which individually they are incapable and that the passions that

14 Suranjan Das, Communal Riots in Bengal 1905-1947 (Delhi: Oxford University Press, 1991).

15 Das and Nandy, 'Violence, Victimhood,' 177-90.

16 Shail Mayaram, 'Speech, Silence and the Making of Partition Violence in Mewat,' in Subaltern Studies IX: Writings on South Asian History and Society, eds. Shahid Amin and Dipesh Chakrabarty (New Delhi: Oxford University Press, 1996).

17 Gordon Marshall, ed., A Dictionary of Sociology (Oxford: Oxford University Press, 1998), 88. See further, Gustave Le Bon, The Crowd: A Study of the Popular Mind (New York: The Viking Press, 1960), with a new introduction by Robert K. Merton. 
seize crowds can produce action which is either heroic or barbaric. ${ }^{18}$ Paul Brass, on the other hand, refutes this idea as blame displacement, suggesting that crowds cannot be viewed differently as Durkheim suggests. ${ }^{19}$ Donald Horowitz, in his extensive study, The Deadly Ethnic Riot, is also critical of Durkheim's understanding of crowd behaviour, but suggests that crowds can draw support from social approval. ${ }^{20}$ In this respect, the collective behaviour of crowds may differ significantly from individual responses.

Given that some responses by individuals may be irrational, and while not trying to displace the blame as Brass suggests, it is possible that individuals whether in crowds or otherwise may be fuelled by their more 'primordial passions'. This 'mob mentality' may be influenced by their primordial instincts rather than compelled by any broader political aims. Sudhir Kakar also acknowledges that some change has to occur for the outbreak of violence; in this case, the 'communal identity has to swamp personal identity in a large number of people, reviving the feelings of love connected with early identifications with one's own group members and the hate toward the outgroup'. ${ }^{21}$ The 1947 violence in Punjab was marked by atrocities that Horowitz sees as evidence of the 'spontaneous quality of riot behaviour'. ${ }^{22}$ Many of the massacres were carried out by mobs in murderous frenzy. ${ }^{23}$ Horowitz does go so far as to see some planning involved in the attacks, for example, on the refugee trains. But others like Javeed Alam argue that there was 'no involvement of large organisations or the state as the instrument of mass killings'.24

Anders Bjorn Hansen though is more critical and argues that the intentions, intensity and degree of organisation of the violence by communal groupings warrant the violence in Punjab to be understood as a manifestation

18 Donald Horowitz, The Deadly Ethnic Riot (Berkeley: University of California Press, 2001), 35. See further, Emile Durkheim, The Elementary Forms of Religious Life (New York: Free Press, 1995).

19 Brass, Production of Hindu-Muslim.

20 Horowitz, Deadly Ethnic, 35, 344.

21 Sudhir Kakar, The Colours of Violence: Cultural Identities, Religion and Conflict (Chicago: University of Chicago Press, 1996), 192.

22 Horowitz, Deadly Ethnic, 13.

23 Leo Kuper, 'Genocide and the Plural Society', in Ethnicity, eds. John Hutchinson and Anthony D. Smith (Oxford: Oxford University Press, 1996), 270.

24 Cited in Pandey, Remembering Partition, 58. 
of genocide. ${ }^{25}$ Interestingly, partition violence has not traditionally been incorporated into broader accounts of genocide or ethnic cleansing, as we understand these terms today. Recent literature such as Centuries of Genocide, ${ }^{26}$ continues to overlook the massacres that took place in Punjab 1947, as does Mann's analysis of ethnic cleansing. ${ }^{27}$ Some new studies are beginning to examine this period as it provides a useful comparative dimension. ${ }^{28}$ One explanation for this omission is that the term has been deployed in relation to the Holocaust and the post-Cold War violence in the Balkans and Rwanda. This raises the question whether it is appropriate to apply this retrospectively to events in Punjab. However, individual case studies do point to organised and systematic acts. For example, Ian Copland refers to the Muslim expulsion in 1947 from Alwar and Bharatpur as not just a communal episode, but also a case of systematic 'ethnic cleansing', frequently a precursor to genocide. ${ }^{29}$

The 1948 United Nations Convention on the Prevention and Punishment of the Crime of Genocide defines genocide as, 'acts committed with intent to destroy, in whole or in part, a national, ethnical, racial or religious group. ${ }^{30}$ Not all scholars though subscribe to this view, partly due to the omission of other persecuted groups within this limited definition. Hansen interestingly points out that during the partition of Punjab, there was no well-defined category of victim and perpetrator; in fact there was a civil war-like conflict escalating during the handover of power. Furthermore, there were primarily three groups (Muslims, Hindus and Sikhs) and each group was 'capable of being the perpetrator and the victims depending on their power and influence in given areas'. ${ }^{31}$ One of the other problems is that genocide is itself associated, and sometimes used synonymously, with the term 'ethnic cleansing'. Ishtiaq

25 Hansen, Partition and Genocide.

26 Samuel Totten and William S. Parsons, eds., Centuries of Genocide: Essays and Eyewitness Accounts (Abingdon: Routledge, 2013).

27 Michael Mann, The Dark Side of Democracy: Explaining Ethnic Cleansing (Cambridge: Cambridge University Press, 2005).

28 Pippa Virdee, "No-man's Land" and the Creation of Partitioned Histories in India/Pakistan,' in Remembering Genocide, eds. Nigel Eltringham and Pam Mclean (Abingdon: Routledge, 2014).

29 Ian Copland, 'The Further Shores of Partition: Ethnic Cleansing in Rajasthan in 1947,' Past and Present 160 (1998): 216.

301948 United Nations Convention for the Prevention and Punishment of Genocide (Art. 2).

31 Hansen, Partition and Genocide, 3. 
Ahmed, who has been considering this dilemma vis-à-vis partition violence, suggests that 'Ethnic cleansing is a generic term that covers removal of a distinct population - on the basis of ethnic, religious, sectarian and other such factors from a specific territory'. Ahmed argues that while genocide results in the destruction of a nation or people in part or whole, ethnic cleansing can lead to the same but using less severe methods. There is, however, a distinction in 'whether the intention was to rid unwanted people from a territory or to destroy them physically'. ${ }^{32}$ The former was certainly evident in Punjab, which was further exacerbated by the refugees fleeing from the fear of reprisal killings.

Regardless of whether the terms 'genocide' and 'ethnic cleansing' are deployed, a debate still rages regarding the 'spontaneity' or 'planning' of the violence. The role of the local state is important here. For such writers as Brass who see links between partition and post-independence communal violence, the complicity of the local law enforcement agencies and the political motivations of the 'producers' of violence are crucial factors. ${ }^{33}$ Brass has nevertheless termed the Punjab violence as 'retributive genocide' which becomes enveloped in a 'cycle of revenge and retribution', ${ }^{34}$ and the boundaries between victim and perpetrator become completely blurred. Other scholars have suggested that this could be seen as a form of fratricide. This could include not only assaults on the 'other', but also the murder of women of one's own family to spare them from the 'dishonour' associated with rape and abduction. Jason Francisco shares this view and argues that 'the partition stands as the archetype of what I would call nationalist fratricide, the conflict between people of a common cultural heritage'. ${ }^{35} \mathrm{He}$ contends that this is distinct from ethnic conflict, or nationalist genocide, which is characterised by state-sponsored persecution or slaughter of cultural or religious minorities, such as the European Jews. Even Khosla's book, which was first published in 1949, describes the magnitude of horrors of 1947 with the comment that 'history has not known a fratricidal war of such dimensions'. ${ }^{36}$ But it was women who bore the brunt of the most

32 Ahmed, The Punjab Bloodied, 6.

33 Paul Brass, 'The Partition of India and Retributive Genocide in the Punjab 194647: Means, Methods and Purposes,' Journal of Genocide Research 5 (2003): 71-101.

34 Brass, 'Partition of India,' 72.

35 Jason Francisco, 'In the Heat of Fratricide: The Literature of India's Partition Burning Freshly,' in Inventing Boundaries: Gender, Politics and the Partition of India, ed. Mushirul Hasan (New Delhi: Oxford University Press, 2000), 372.

36 Khosla, Stern Reckoning, 4. 
horrific crimes, leading to what could be described as forms of femicide. ${ }^{37}$ There are first-hand accounts of abductions, mass honour killings, women's bodies being mutilated and violated, indescribable crimes aimed at inflicting pain on the 'other'. These accounts have largely remained buried under the burden of prioritising the immediate needs of the nation and to recover the so-called izzat of the nation.

Furthermore, the notion of a hierarchy of suffering can also be applied to the partition violence itself. Leaving aside the global perspective, one only has to look to the 'chief sufferers' of partition violence and migration. ${ }^{38}$ The plight of the women, low castes and children has only recently begun to be addressed by scholars, with a new generation of writers willing to tackle and challenge taboo subjects such as violence, rape and the abduction of women allowing some barriers to be broken..$^{39}$ It is estimated that 75,000 women were raped and abducted during this time on both sides of the border, although Khosla estimates the number of abducted women at 200,000 or more. Women were brutalised and dishonoured to inflict collective wounds on the 'other'. This also triggered 'pre-emptive' sacrifices by women to prevent 'dishonour' in the family. The most quoted episode is of the Sikh women in Thoha Khalsa (in Rawalpindi district, Pakistan), which has been immortalised since Butalia recovered this account in The Other Side of Silence during the March 1947 massacres in Rawalpindi. ${ }^{40}$ The account begins with Sant Raja Singh who took the life of his daughter and martyred her after praying and asking for forgiveness. This is then followed by Sardarni Gulab Kaur, who plunged into the well and committed suicide rather than be dishonoured. In total around ninety women, all of one lineage, perished. The account has been used to show the bravery and courage of the women. Further, Rameshwari Nehru (who was a social worker and head of the Women's Section in the Ministry of Relief and Rehabilitation) likened the 'pre-emptive' sacrifices to the old Rajput

37 This concept has its roots in feminist discourse, where violence is viewed as a tool of repression and male dominance. For a discussion on this, see Jill Radford and Diana E. H. Russell, eds., Femicide: The Politics of Woman Killing (Buckingham: Open University Press, 1992).

38 Andrew Major, 'The Chief Sufferers: The Abduction of Women during the Partition of the Punjab,' South Asia XVIII (1995): 57-72.

39 Urvashi Butalia, The Other Side of Silence: Voices from the Partition of India (New Delhi: Penguin,1998); and Ritu Menon and Kamla Bhasin,Borders and Boundaries: Women in India's Partition (New Jersey: Rutger University Press, 1998).

40 Butalia, The Other Side. 
tradition of self-immolation in which women sacrificed themselves on the funeral pyres of their husband. ${ }^{41}$ Shauna Singh Baldwin, however, questions the patriarchal discourse associated with this, which she terms as 'bravery', 'duty' and 'martyrdom'. ${ }^{42}$ By doing so, the violent act performed by the male head is justified. The fact that some women did not die and others were not so forthcoming for this 'sacrifice' is less visible and what is remembered is the 'heroic' act. Crucially writers such as Veena Das refute this, and argue that these women have simply become objects of national honour and serve only to promote the interests of the newly created nation-states. ${ }^{43}$

Those who regard the violence as unplanned either ignore the role of the state or maintain that its collapse in 1947 was a crucial factor in explaining the outbreaks. The main difference between the violence in the years preceding partition and the partition violence itself is that in the former there was still a functioning government, admittedly a weak one, on occasions. The collapse of state authority during the transitory period of transferring power is probably one reason why the violence was so widespread and horrific during the months following partition. As is discussed later in chapter five, during my research on Malerkotla, a small Muslim princely state in the Indian Punjab, the role of the state was crucial in maintaining law and order; consequently Malerkotla remained a haven of peace for Muslims while surrounded by the partition violence in neighbouring British India. ${ }^{44}$ Conversely the riots that occurred in Rawalpindi in March 1947 followed the resignation of the minority government formed after the election of 1946 by Unionist Khizr Hayat Tiwana. ${ }^{45}$ Arguably then, the vacuum created by the absence of a functioning authority was a prerequisite for violence to occur in Rawalpindi and was certainly prevented in Malerkotla.

\section{The State and the Making of a Refugee}

At the end of August, two weeks after partition had taken place, there was, however, still some hope that the law and order situation would improve.

41 Pandey, Remembering Partition, 88.

42 Shauna Singh Baldwin, What the Body Remembers (London: Anchor, 2000).

43 Veena Das, Critical Events: An Anthropological Perspective on Contemporary India (Delhi: Oxford University Press, 1995), 70.

44 Pippa Virdee, 'Partition and the Absence of Communal Violence in Malerkotla,' in Talbot, The Deadly Embrace.

45 Tahir Kamran, 'The Unfolding Crisis in Punjab, March-August 1947: Key Turning Points and British Responses,' Journal of Punjab Studies 14 (2007): 187-210. 
Indeed, 'the Prime Minister of Pakistan expressed the hope that, as the general situation improved, those gathered in refugee camps would return to their homes' ${ }^{46}$ Many of the refugees that I have interviewed, and discussed later in this chapter, have frequently said that once the troubles settled down, they had hoped to return to their ancestral homes.

However, it was also beginning to dawn on the authorities that some movement of peoples was inevitable due to the uncontrollable levels of violence. The Defence Minister of Pakistan, Liaquat Ali Khan, wrote to the Governor-General of India, Mountbatten, on 28 August 1947:

From all reports conditions in Eastern Punjab are far worse than could have been imagined. In Amritsar, Hoshiarpur, Jullundur districts and parts of Gurdaspur, Ludhiana and Ferozepore districts complete breakdown of administration. Thousands of men, women and children massacred and large proportion of Muslim villages burnt. Abduction on a large scale. Reign of terror in these districts has driven hundreds of thousands to West Punjab. Number of Muslim refugees may run upto a million or more. ${ }^{47}$

In the telegram, the minister notes that the refugees may run into a million or more, and of course this number escalated into many millions by the end of 1947. He goes on to say that it appears the Sikh objective is to 'exterminate or drive out entire Muslim population from this area'. ${ }^{48}$ One of the bloodiest massacres was in Sheikhupura. G. D. Khosla terms the district as a 'by-word', 49 for murder, loot, arson and rape that took place between 17 and 31 August. ${ }^{50}$ In a statement sent to Rameshwari Nehru, the extent of the partition violence becomes clear. The statement notes that in the space of 24 hours, 10,000 people were killed in Sheikhupura by the "Muslim military and police or were burnt

46 Minutes of the sixth meeting of the Joint Defence Council held at Government House, Lahore, 29 August 1947, in Singh, Select Documents, 505.

47 Defence minister, Pakistan, to governor-general, India, 27 August 1947. National Documentation Centre (NDC), Disturbances in the Punjab, 1947: A Compilation of Official Documents (Islamabad: Government of Pakistan, 1995), 365.

48 Defence minister, Pakistan, to governor-general, India, 27 August 1947. NDC, Disturbances in the Punjab, 365.

49 Khosla, Stern Reckoning, 126-40.

50 Menon and Bhasin, Borders and Boundaries, recount the story of Dr. Virsa Singh, who says that he personally killed fifty women in Sheikhupura to save their honour. 
alive in the houses'. In this case it appears that the Baloch soldiers and the local leadership were culpable for the massacre but the statement also notes how some people, regardless of the dangers, were compelled to save and protect the lives of the 'other' community. For example, 'the local president of the league, Mr. Anwar had given shelter to about 65 members of the families of his friends. One Mrs. Rafi, a wife of a police inspector saved about 70 lives, ${ }^{11}$ highlighting that even in this extreme situation not all humanity had vanished.

Sheikhupura district included Nankana Sahib and thus was the spiritual homeland of the Sikh community, as it is the birthplace of the founder of Sikhism and for this reason alone many Sikhs found it difficult to believe that it would now be in Pakistan. But like the rest of central Punjab, the district was an amalgam of different religious communities who came to co-exist over generations. ${ }^{52}$ Yet, now nearly 150,000 Sikhs were gathered for the mass exodus..$^{53}$ They took refuge in local schools and gurdwaras and the Sacha Sauda camp alone had over hundred thousand people as refugees from neighbouring areas all gathered. ${ }^{54}$ The creation of refugees by these acts of violence left people helpless in their loss of family members and property. Some wrote to religious organisations such as the Hindu Mahasabha in desperate pleas of help:

I am refugee from Sheikhupura proper which has been a scene of total mascure [sic] and I have lost six members of my own family including brother, his wife two daughters one son and my own wife. Now I have to look after two families myself alone. I, therefore request that a suitable quarter for ten members may kindly be allotted to me to live in...At present, I am staying in a refugee camp in New Delhi. I beg to point out that we had at Sheikhupura three houses and 50 bighas [1 bigha is roughly equivalent to $1 / 3$ of an acre] of cultivated land and all our houses and property has been looted by the rioters. Now I am absolutely penyless $[\mathrm{sic}]^{55}$

51 Rameshwari Nehru Papers, no. 25, four-page statement about Sheikhupura sent from Lahore, 28 August 1947. NMML, New Delhi.

52 See the chapter on 'Composite Culture in Pre-Partition Punjab.' Meeto (Kamaljit Bhasin-Malik), In the Making: Identity Formation in South Asia (Gurgaon: Three Essays Collective, 2007).

53 Sir Francis Mudie to Mr Jinnah, 5 September 1947, in Singh, Select Documents, 511.

54 Menon and Bhasin, Borders and Boundaries, 49.

55 Letter sent to the Magistrate, 17 September 1947, by Prem Nath. Hindu Mahasabha, File C-168. NMML, New Delhi. 
Until September 1947, the governments were unable to accept the reality that a mass transfer of population was necessary. Once the violence reached uncontrollable levels and chaos engulfed the Punjab region, the two new dominions had to accept that the exchange of populations was an inevitable outcome of partition. There were fears that the "holocaust at Sheikhupura will probably be repeated in many other mofussil areas in West Punjab and that 40,000 lives are in danger during next 48 hours'. It was therefore recommended that a 'transfer of population should take place'. ${ }^{56}$ But the nature of that exchange was not clear. Would the exchange involve repatriation or resettlement? Mahatma Gandhi's view on this was that 'the migrants must eventually return to their homes and lands that the two Dominion Governments must extend the fullest protection of their minorities'. ${ }^{57}$ In many ways, the refugees themselves were of the same opinion. The interview below with a migrant from Sialkot, which resonates in many other oral accounts of refugees' experiences, illustrates the hope that uprooting would only be temporary. Sarwan recollects:

People just tied locks to their houses in our village. We told our neighbours that we would be back soon. Some people who were our sympathisers said not to go. People lost a lot, most left everything there. We had one horse and brought along as much as we could. We didn't know that we would not return. We just went until things calmed down..$^{58}$

Similarly, in Manto's The Assignment, there is quiet optimism about the communal violence, 'two weeks or so of unrest and then business as usual'. It was seen as 'temporary inflamed political passions', ${ }^{59}$ which would soon subside. And so people began to move but only temporarily. These views were reiterated in an interview with Rana, who migrated from Ludhiana. Like many others, he thought that eventually there would be an opportunity to go back to their ancestral lands but even with this hope in mind, it was still an emotional and painful process.

When we migrated from India, many Muslims thought that they would come back after two to three months. It was stupidity, I think. Even

56 Letter to Nehru from High Commissioner for India Camp, Lahore, 27 August 1947, in Singh, Select Documents, 502.

57 After Partition (Delhi: Publications Division, Government of India, 1948), 59.

58 Interview with Sarwan Singh, Lal Bazaar, Malerkotla, August 2001.

59 Saadat Hasan Manto and Introduction by Daniyal Mueenuddin, Mottled Dawn: Fifty Sketches and Stories of Partition (India: Penguin, 2011), 11. 
feeling all this, we were not sure about migration...The riots kept on gaining strength and ferocity and only two options were left with us to die or to migrate. Some Muslims wanted to stay in their homeland and die there while the rest thought about the other option because the army of the [Sikh] States had surrounded them and they didn't have weapons to defend themselves. Some of our Sikh friends waited for us on the way. At the sight of my maternal uncle, they started crying and embraced him. They gave us some bread and few other items of necessity. They loaded those items on a horse and handed the reins to us. ${ }^{60}$

It was first noted on 7 September 1947 at the Emergency Committee meeting between India and Pakistan that the movement of people was their first priority. ${ }^{61}$ Conceived as an afterthought, the ineffectual Punjab Boundary Force, ${ }^{62}$ which comprised of Indian and Pakistani troops under a British commander, Major General Thomas Wynford Rees, was wound up. Rather than protecting everyone, the Punjab Boundary Force was seen to be taking sides and communally divided. ${ }^{63}$ Both governments had vowed to cooperate and to use all resources available to them to provide safety for migrants. ${ }^{64}$ The Punjab governments set up the Liaison Agency, to oversee the evacuation of refugees, which was headed jointly by two chief liaison officers (CLOs) based in Lahore and Amritsar. Each district also had a district liaison officer (DLO) who relayed information to the CLO about ground activities regarding the status of refugees and evacuation plans. This agency along with the Military Evacuation Organisation (MEO) was responsible for the movement of people across the borders of Punjab. They determined the priorities for the movement of evacuees based on the reports provided by the district officers and in consultation with a priority board. ${ }^{65}$

60 Interview with Rana, Chiniot Bazaar, Faisalabad, February 2003.

61 Brigadier Rajendra Singh, The Military Evacuation Organisation 1947-48 (New Delhi: Government of India, 1962), 11-12.

62 See further Robin Jeffrey, 'The Punjab Boundary Force and the Problem of Order, August 1947,' Modern Asian Studies 8, no. 4 (1974): 491-520.

63 Defence minister, Pakistan, to governor-general, India, 27 August 1947. NDC, Disturbances in the Punjab, 365.

64 Pippa Virdee, 'Partition in Transition: Comparative Analysis of Migration in Ludhiana and Lyallpur,' in Partitioned Lives: Narratives of Home, Displacement and Re-settlement, eds. Anjali Gera Roy and Nandi Bhatia (New Delhi: Pearson, 2007).

65 Satya Rai, Partition of the Punjab: A Study of Its effects on the Politics and Administration of the Punjab 1947-56 (Bombay: Asia Publishing House, 1965), 78. 
In the immediate aftermath of partition, the Indian government was on average shifting 50,000 Hindus and Sikhs a day. ${ }^{66}$ All modes of transport were used - railways, motor trucks, foot convoys and aircraft. Generally, large foot convoys were utilised by rural migrants as they could transport their cattle and bullock carts, whereas trains were easier for evacuating urban migrants. Compelling images of partition remain the foot convoys, kafilas, ${ }^{67}$ which stretched over many miles and the trains with their compartments and roof spaces packed with refugees. ${ }^{68}$ The kafilas like the trains were the target of attacks by Muslims and non-Muslims alike, even though they were assisted by the military. From Table 4.1, we can see that the MEO managed to assist the evacuation of the majority of people by the end of November. The figures in the table are not the final totals as there were still pockets of people who were stranded. In addition to the modes of transport listed, there were about 30,000 people who were evacuated by air from West Punjab. ${ }^{69}$ By 26 November 1947, the MEO's task of evacuating people was nearly complete, with the exception of some pockets of people in remote areas, abducted women, converted people, and scheduled caste ${ }^{70}$ refugees who still required their assistance. ${ }^{71}$

Table 4.1: Evacuation Figures - Total upto 22 November 1947

\begin{tabular}{lccc}
\hline & Non-Muslims & Muslims & Total \\
\hline By motor transport & 349,834 & 215,690 & 565,524 \\
By rail & 849,500 & 943,720 & $1,793,220$ \\
By foot & $1,014,000$ & $2,385,165$ & $3,399,165$ \\
Total & $2,213,334$ & $3,544,575$ & $5,757,909$ \\
\hline
\end{tabular}

Source: Weekly Reports on Refugees, 23 November 1947, Liaison Agency Files, LVII/26/45, PSA.

The vast majority of people crossed the newly created border on foot, forming snake-like kafilas which, though protected by the army, were still attacked by the opposing communities who were themselves going in the

66 After Partition, 52.

67 See further, Margaret Bourke-White, Halfway to Freedom: A Report on the New India in the Words and Photos of Margaret Bourke-White (New York: Simon \& Schuster, 1949).

68 Khushwant Singh's fictional novel has most poignantly captured the emotion and fear of these train journeys experienced by some two million people. See further, Train to Pakistan (London: Chatto \& Windus, 1956).

69 Singh, Military Evacuation Organisation, 108.

70 Official term for untouchables.

71 Singh, Military Evacuation Organisation, 109. 
opposite direction. For others, the exhaustion of travelling was too much; the weak were simply left to perish, while the dead were abandoned without any burial rites. Foot convoys regardless of these problems remained the most practical method of transport for the largely agricultural Punjabi community, who could at least take some essential foodstuff, equipment and cattle with them. The trains were the second most popular form for transporting the refugees, yet the history of partition is replete with horrific stories of preplanned attacks on trains, trains filled with corpses denuded of all identity and of burning trains arriving at platforms and motivating further reprisal killings. Some were lucky enough to survive:

They [Sikhs] blocked the way of our train - halting our journey for three days. It seemed that the Sikhs were preparing for a big attack. There were four to five military men of Baloch regiment with us. With great effort of these soldiers our train set off again. Going on a little ahead, we found scores of Sikhs lying on the ground, who were ready to attack our train. Our military men opened fire on them and the entrenchments of Sikhs became their graves. ${ }^{72}$

Khushwant Singh's fictional account is perhaps the most widely quoted reference which captures all the absurdities of partition and is set in the background of trains travelling between new borders. ${ }^{73}$ It portrays Mano Majra, once a sleepy village but now on the newly created border between India and Pakistan. The book poignantly ends with the dilemma facing the main protagonist over what action they, as individuals, should take regarding a planned attack on a train headed for Pakistan with Muslim refugees. Train to Pakistan, written in 1956, was an important piece of fictional writing because it brought out the human dimension of partition. Rather than focusing on the 'great men', Singh was telling the story of how the decisions taken by them affected ordinary villages like Mano Majra and how their lives are thrown into turmoil by these decisions made faraway.

A refugee recalls the moment when Muslim and non-Muslim kafilas crossed each other near Wagah, which poignantly illustrates that sometimes the refugees' shared suffering was able to overcome hostility.

72 Interview with Saleem, Faisalabad, December 2002. Saleem migrated from Ludhiana.

73 Singh, Train to Pakistan. 
They stopped where they were, and we stopped where we were. They were Muslim and we were non-Muslims. And no one spoke. We went on looking at each other. They had left their homes and friends behind, and so had we. But there was a strange kind of kinship, this kinship of sorrow. We were all refugees. We both had been broken on the wreck of history. ${ }^{74}$

The sentiments echo those of the poet Daman, when he says, 'that you have lost, as we too have lost in this divide'. In the end, approximately 7.3 million people crossed into India, 6.5 million into Pakistan, and 0.7 million into Bangladesh. The same figures taken as a percentage present a different story, 2.04, 20.9 and 1.66 per cent, respectively; the task for Pakistan is proportionally much more significant. ${ }^{75}$

Upon arrival, the refugees sought refuge in any makeshift accommodation that was available to them. Schools and colleges were closed until the end of February 1948 so that the buildings could be used as temporary shelter. Students were enlisted to assist the running of the camps. Other temporary camps had to be erected to cope with the masses of refugees. While there were camps dotted all over the Punjab, there were also so-called 'concentration camps', like the Walton Camp in Lahore and the Kurukshetra Camp in present-day Haryana, which were focal points for the movement of people. Such camps were responsible for housing as many as 300,000 people at any one time. ${ }^{76}$ These facilities had to be improvised rapidly to accommodate the unanticipated tide of refugees.

Despite being in refugee camps and being stateless, the journey across the new border marked a sense of relief for many refugees - Stephen Keller makes the analogy with the feeling of having reached the 'promised land' ${ }^{77}$ In an interview with Kabir, he also recalled the sense of relief felt by everyone upon reaching Atari, comparing it to a religious shrine which they had finally

74 Andrew Whitehead, 'Refugees from Partition,' in India Disasters Report: Towards a Policy Initiative, eds. S. Parsuraman and P. V. Unnikrishnan (New York: Oxford University Press, 2000).

75 Prashant Bharadwaj, Asim Ijaz Khwaja and Atif Mian, 'The Big March: Migratory Flows after the Partition of India,' HKS Faculty Research Working Paper Series RWP08-029, June 2008, 7, accessed 21 May 2017, www.hks.harvard.edu.

76 After Partition, 56.

77 Stephen Keller, Uprooting and Social Change: The Role of Refugees in Development (New Delhi: Manohar, 1975), 59. 
reached. ${ }^{78}$ But this jubilation was short-lived. Makeshift refugee camps accommodated the millions who were uprooted, homeless and destitute and by the end of December 1947, there were more than 160 refugee camps all over India and 85 of those were in East Punjab. ${ }^{79}$ August and September were still part of the monsoon season and this hampered the logistics of the evacuation process even further. It was noted that 'floods washed away roads and railway tracks and bridges, broke up transport and communications...mercilessly washed away the evacuees who were encamping in low-lying areas between Amritsar and Jullundur'. ${ }^{80}$ Refugees themselves vividly recount stories of the floods sweeping in swollen bodies and blood-flowing rivers, images they are unable to confine to the past. Khurshid recounts her experiences:

We witnessed atrocities of Hindus and Sikhs towards Muslims. They murdered Muslims brutally and shattered their bodies to pieces with spears. Displayed the corpses in the air on their blades and threw them on the earth afterwards. Those were the rainy days and water became red with blood of the corpses lying unattended on the ground. When we started from there, our feet got red with the bloody water. ${ }^{81}$

Khaira's account in Talbot and Tatla's Epicentre of Violence highlights the extent to which people became quite immune to otherwise disturbing and horrific accounts, which was for many the only way to survive the experience.

During the movement of the convoy we used to drink water from a small stream which ran parallel to the passage. I remember, many times when we drank water from the stream, there were dead bodies flowing through it, one bloated body passing, then another one coming from the distance. This chain of dead bodies hardly stopped. People would just wait to let the body pass before filling their glasses of water. ${ }^{82}$

The impending winter presented further problems, with provision of warm clothing and blankets becoming a priority for the Governments of India

78 Interview with Kabir, Jhang Bazaar, Faisalabad, February 2003.

79 Department of Relief and Rehabilitation, Punjab, Millions Live Again: A Survey of Refugee Relief in East Punjab (not dated).

80 Millions Live Again, 4.

81 Interview with Khurshid, Raza Abad, Faisalabad, February 2002.

82 Interview with Sardar Bhaqwant Singh Khaira in Ian Talbot and Darshan Singh Tatla, eds., Epicentre of Violence (Delhi: Seagull, 2006), 53. 
and Pakistan. While the provision of clothing, food and housing was at least something which could be calculated and catered for, the psychological impact of this trauma is something which has received little attention. One of the earliest studies was by Stephen Keller who spent time with Sikh and Hindu Punjabi refugees and tried to examine the social impact of this displacement. In his study, Keller identifies three stages in the refugee experience. The first one, which is relatively short, is the point of arrival in which the refugee is numbed by the experience and often overcome by grief. The second stage is survivor's guilt. Keller recounts a story of a man who became separated from his mother and came to Amritsar. There was a sense of guilt because his mother had been left behind, while he had survived. As a result of these feelings, he became restless, anxious and incapable of settling down. The continued inability to reconcile to this separation and the associated guilt eventually led him to Pakistan, to search for his mother, and although he was not able to locate her, there was at last some sort of closure for him. ${ }^{83}$ This sense of restlessness felt by refugees and the inability to settle down resonates in many accounts provided by refugees. The final stage, according to Keller, is marked by aggression, not necessarily physical aggression but a stage in which the refugee feels invincible enough to take risks; this could be risks in business or even in the political sphere. As one of the refugees says, 'we have gone through so much; what more can happen to us? No one can do anything to us that can be more terrible than has already occurred. Why should we be afraid?'84

\section{Rehabilitation of Bodies and Minds}

One area where we witness women's agency at work is through the women who were assisting in the refugee camps and the rehabilitation of refugees. While reading the reports in The Pakistan Times it is obvious that the task of refugee rehabilitation was too great for the newly established Government of Pakistan and the Muslim League to handle alone; it required combined efforts. Consequently, groups that were the most capable, such as local students, were enlisted to assist with the unfolding human tragedy. Women were also taking the initiative themselves and organising and mobilising other women to work and contribute in refugee camps. Indeed, this was a crucial time for Muslim women to come out of seclusion (purdah) and assist in the rehabilitation process. It was an appeal to their maternal instincts, but moreover, it was also

83 Keller, Uprooting and Social, 62-3.

84 Keller, Uprooting and Social, 116. 
an opportunity for women to improve and educate themselves. As these reports from The Pakistan Times show, girls were encouraged to aid in the relief and rehabilitation of women and as a result the students of Islamia College for Women, Lahore, organised themselves into groups. They made trips to the Mayo Hospital daily for distribution of clothes to sick refugees and were also involved in writing letters or broadcasting messages for the illiterate. In a press note released by the Ministry of Refugees and Rehabilitation, it was noted that 'so far they have delivered 1,200 clothes to the refugees in the hospital and written hundreds of messages' ${ }^{85}$ In addition to this, the college also opened classes for knitting and sewing, with all members of staff and students involved in voluntary work; this was in the form of contributing forty minutes of their time every day which was spent knitting jerseys and sweaters. The college, in a further effort to aid the rehabilitation of girls, decided to admit refugee students free of tuition fees and also provided free board in their hostel. ${ }^{86}$

The partition violence left the medical services stretched to the limit in dealing with the wounded and maimed women and children. In addition, the lack of fully trained support further hindered this desperate situation. Soon after partition there was an appeal by Fatima Jinnah, who had formed the Women's Relief Committee, '... to Muslim nurses and Muslim girls and women trained in first aid to offer their services for the noble cause of saving the lives of hundreds of their unfortunate sisters' ${ }^{87}$ Those willing to do this work were instructed to contact the women's section of the Muslim League. Interestingly, some of the initiatives took place before the official response by the state authorities, again emphasising the importance of how people often used their own networks and initiatives to mobilise support and provide aid for refugees.

One of the earliest initiatives was the establishment in 1948 of the Pakistan Voluntary Service (PVS) in Lahore, formed under the guidance of Begum Liaquat Ali Khan, ${ }^{88}$ Miss Macqueen, Begum Shah Nawaz, ${ }^{89}$ and Fatima

85 The Pakistan Times, 30 October 1947.

86 The Pakistan Times, 30 October 1947.

87 The Pakistan Times, 7 September 1947.

88 In 1949, Begum Ra'ana arranged a conference with women from all over Pakistan; this resulted in the creation of the All Pakistan Women's Association. This was a voluntary and non-political organisation designed to support and strengthen women socially, culturally and through improved provision of education.

89 Begum Shah Nawaz and Begum Shaista Ikramullah were the only two women in the Pakistan Constituent Assembly and Central Legislature in 1947. Shah Nawaz was also one of the founding members of the All Pakistan Women's Association. 
Jinnah. ${ }^{90}$ Begum Ra'ana Liaquat Ali Khan was the wife of the first Prime Minister of Pakistan and assumed a leading role in the women's voluntary service. The organisation encouraged women to take up responsibilities such as the administration of first aid, distribution of food and clothing, dealing with health problems and epidemics but voluntary help also took the form of providing the refugees with the much needed moral and emotional support. Begum Shah Nawaz, a leading Muslim League figure and a member of the Constituent Assembly, made an appeal to women in West Punjab to come forward and work for the noble cause as she saw it. In a statement on 23 September 1947, she said:

\begin{abstract}
...Their mangled bodies, their tear-filled eyes and their trembling hands await whatever succour and hope we can give them. At this hour, it is the duty of every Pakistani man, woman and child to do his or her duty. My sisters, you have never failed your nation. When patriotism called, you came forth in thousands and did not hesitate to face lathi, tear-gas and bullets and some of you went to jail. Today your country needs you as never before...You are the real soldiers of Pakistan. Your motherland needs you. Your helpless sisters await your aid. You have never failed your nation before I know that you will not fail now. ${ }^{91}$
\end{abstract}

Initially, there was a good response to this appeal and hundreds of women had offered their voluntary services to PVS regardless of the problems with transport and logistics which hampered the relief process. Begum Shah Nawaz, who was a special assistant in Rehabilitation and Employment, was keen to maintain the momentum and appealed to every woman to register her name in the women voluntary service's register. ${ }^{92}$ However, a week later, there was a report in the newspaper again noting the lack of women who were willing to come forward and volunteer:

Many women who stayed back from enrolling their names did so because they felt they were not sufficiently educated. It will surprise them to find that the kind of help needed in the refugee camps and hospitals is what

90 Fatima Jinnah is referred to as Madr-e-Millat, mother of the nation. She played a leading role in the resettlement of refugees and was proponent of women's emancipation, encouraging their participation in the creation of the Pakistan state.

91 The Pakistan Times, 23 September 1947.

92 The Pakistan Times, 1 October 1947. 
most of us are competent to render. To comb a dusty head with wounds and blood clots, to wash faces smeared with dirt and tears, to soothe the nerves of an old woman broken in body and spirit both - to comfort a young mother who has been tossed off this side of the shore to face an uncertain destiny at the hands of the strangers - these are activities for which any woman is trained, and while rendering them, she will be educating herself further. ${ }^{93}$

There are many accounts and reports of Fatima Jinnah visiting camps, not only to boost morale but also to highlight the important work being done by individuals on a daily basis. This served as a further incentive for more women to become involved in the rehabilitation of refugees. On one such visit, The Pakistan Times on 30 October 1947 reports:

Miss Jinnah, who was shown round a number of refugees, in particular to stranded women and girls recovered from non-Muslims. She expressed her deep sympathy with them in their suffering. There were a number of lady volunteer workers busy helping the refugees in the camps. Miss Jinnah appreciated their work. Begum Azin Ullah is in charge of these workers. She explained that there is a batch of 60 workers who work in two shifts. ${ }^{94}$

In October 1947, the West Punjab government also opened an 'Industrial Home for Mohajir widows and destitute women of middle classes to give them industrial training, which would enable them to earn independent living in due course'. ${ }^{95}$ The training provided not only ranged from work skills such as tailoring, embroidery work, spinning and weaving of tape, to the more immediate concerns of the nation like elementary nursing and first aid, but also provided for religious instruction. ${ }^{96}$ Trainees were provided with free boarding and lodging but with the hope that they would eventually become self-sufficient once they started earning money. Employment exchanges were set up in order to find suitable positions for women. Other social services were also available, notably, marriage bureaus were set up where names of girls and boys of marriageable age were entered in order

93 The Pakistan Times, 7 October 1947.

94 The Pakistan Times, 30 October 1947.

95 The Pakistan Times, 15 October 1947.

96 The Pakistan Times, 15 October 1947. 
to find them suitable partners. ${ }^{97}$ Lahore was the main hub of activities where homes for destitute women such as the Sir Ganga Ram Widows' Home and also a Girls Training College were established. Women who were rescued from East Punjab were brought to homes such as these if no relatives were traced.

The women whowere at the forefront of these activities were predominantly from elite backgrounds; they were articulate and able to organise and generate support for assisting refugees. We, therefore, repeatedly see the names of women like Fatima Jinnah, Begum Liaquat Ali Khan, Miss Macqueen and Begum Mumtaz Shah Nawaz being reported as taking a leading role in organising these activities. While it was essential to have this strong female leadership, more practical and urgent assistance was also required in the form of collecting bedding, blankets and warm clothing due to the onset of winter. On 20 December, there was yet another public appeal: 'Help is required from every one especially women. I mention women, because after all they are the managers of the household. Winter clothes help should primarily be their concern. Let the women of Pakistan prove that they are good managers' ${ }^{98}$ There were also recommendations for 'every housewife' to follow which would greatly benefit the 'cause of humanity'. The advice is simple:

Why not organise a knitting competition in your moballa or your town. Young girls would love to show their prowess, and every week there would be a fair collection of knitted garments to send to the refugee relief centres. These are some of the things which women can do to help in this great task before the country. Remember, each garment you give will save a human life. ${ }^{99}$

What these newspaper reports show is the active role of women in the rehabilitation of refugees in Pakistan. They were integral to the needs of ensuring that the refugees had some support and assistance when they arrived in camps. Women helped in camps, provided medical care, domestic help and education or even just merely donated warm clothing for the refugees. It enabled women to become active agents in the creation of the new state and saw an increasing number of women come out of seclusion to assume a greater role in society.

97 The Pakistan Times, 11 October 1947.

98 The Pakistan Times, 20 December 1947.

99 The Pakistan Times, 20 December 1947. 
Evidently both the governments of India and Pakistan were surprised, and unprepared for the movement of people; many of the people themselves had no plans to move either. As refugees, some found acceptance, others moved around until they settled, and the rest found the promised land did not welcome them. Tatla depicts the experience of one family from the Sandal Bar:

Yes, we were taunted by the term, sometimes called panahgir, more often,
refugees. Someone will say, look,' a refugee is here'. We would try to divert
the conversation by saying, 'we are your brothers' and sometimes argue
'we are not refugees, and we have come back to our native lands', did
not we have everything here? [sic] Some did help us, others were hostile.
'Refugee' was a shameful term, a tag we carried for year, [sic] whenever
the term was mentioned, we felt ashamed. It still does. ${ }^{100}$

Their common religious identity was not always enough for them to be assimilated easily into the new landscape but they were stuck with the language of religious labels such as panahgirs or mubajirs ${ }^{101}$ for Muslim refugees and sharanarthis for Hindu and Sikh. ${ }^{102}$ The term mubajir has largely become an important source of identity for Urdu-speaking partitionrelated migrants and their descendants from the United Provinces living particularly in Karachi. It is therefore mostly associated with the Urduspeaking people, rather than the Punjabi migrants. The terms themselves also disguised the fact that they were now aliens in their own lands. The label of 'refugee' was etched upon them permanently, a term to be associated with the destitute, helpless, and homeless. But over time, this temporary dislocation turned into a fragile permanence and with that a new identity emerged. They had not chosen this necessarily at the point of departure but there was little chance of now returning to what they had known before their lives were ruptured.

100 Darshan Singh Tatla, 'The Sandal Bar: Memoirs of a Jat Sikh Farmer,' The Panjab Past and Present 29, nos. 1 and 2 (1995): 173.

101 The word, however, had very different connotations because mobajir is an Arabic word meaning immigrant or emigrant and is associated with the migration of the prophet Muhammad and his companions when they left Mecca for Medina.

102 Vazira Fazila-Yacoobali Zamindar, The Long Partition and the Making of Modern South Asia: Refugees, Boundaries, Histories (India: Penguin, 2007), 8. 


\section{Khwaja Fariduddin Masud Ganjshakar, popularly known as Baba Farid ${ }^{1}$}

Farid, if you are maltreated

Do not react with violence and projection

Visit the Other

And kiss his feet in humility and affection!

Farid, do not belittle the dust

The living march on its bed

The dead are buried under its crust

Farid, meet evil with good

Show no hatred or revenge

Your being will stay away from vanity

Healthy and pure in serenity

\section{Mian Muhammad Baksh}

\section{Saif-ul-Malook ${ }^{2}$}

Dushman marey tey kbushee na karey, sajnaa wee mar janaa,

Deegar tey din gayaa Mohammad, orrak noon dub jana.

Do not rejoice at the death of your enemy because your friends too have to die, The afternoon sun is soon going to set.

1 Harjeet Singh Gill, Sufi Rhythms: Interpreted in Free Verse (Patiala: Punjabi University, 2007), 5, 7 and 14.

2 Suf Poetry, accessed 8 October 2016, https://sufipoetry.wordpress.com/category/ mian-muhammad-baksh/. 